\author{
Jasmina Naumoska \\ Univerzitet »Sv. Kiril i Metodij« vo Skopje, Filozofski fakultet, Bul. Goce Delčev 9A, MK-1000 Skopje \\ jasmina.naumoska@fzf.ukim.edu.mk
}

\title{
Suvremeni metodološki izazovi u tumačenju predsokratovske filozofije
}

\begin{abstract}
Sažetak
Povijest filozofije, shvaćena kao djelatnost koja u novim kontekstima iznova iščitava prošlost filozofije, uvijek mora biti suočena s interpretativnim metodološkim izazovima svoga vremena. Suvremena interpretacija predsokratovaca mora iznova odgovoriti na pitanje o tome što predstavlja predsokratovska filozofija, mora odrediti pristup u tumačenju odgovarajućih metoda koje će koristiti, mora ocijeniti koliko sadašnji pogled na svijet može odstupiti od povijesno-filozofske realnosti, ali i mora postaviti minimum standarda za metodološki odgovarajuću interpretaciju.

U ovom problemskom okviru, preko identificiranja nekih suvremenih interpretativnih tendencija u pogledu predsokratovske filozofije, ovaj tekst problematizira identitet predsokratovaca, analizira pristupe "filozofske sinteze», "filološke analize" $i$ »ilozofske analize", uočava napore za nadilaženje određenih interpretativnih stereotipa, ali i postavlja osnovne uvjete za metodološki odgovarajuću interpretaciju. Pri tome, u ovom tekstu ukazuje se na to da ako filozofiju shvatimo kao stalno otvoreni i nezavršeni proces, onda i povijest filozofije, kao imanentno filozofska disciplina, ne može postaviti zauvijek definirane metodološke standarde.
\end{abstract}

\section{Ključne riječi}

predsokratovci, interpretacija, metodologija, suvremena filozofija

Pristup jednom povijesno nedovoljno poznatom filozofskom kontekstu, kakav je s današnje točke gledanja kontekst predsokratovske filozofije, zahtijeva specifičnu metodološku pripremu i opremljenost. Najprije, potrebno je prihvatiti određene opće stavove u odnosu na pitanja koja postavlja filozofija povijesti, zatim odrediti opća i posebna metodološka pravila i instrumente za tumačenje filozofije tog određenog povijesnog konteksta, poznavati jezik preko kojega je ta filozofija nama prenesena i, na kraju, potrebno je vrednovati taj filozofski period ili konkretni filozofski sistem imajući u vidu da povijest filozofije ima didaktičku funkciju.

Smatra se da je, izuzmemo li biblijski tekst, najviše interpretirana tekstualna kompozicija u povijesti čovjekove stvaralačke tradicije Platonov filozofski korpus. Zato se u okvirima metodologije povijesti filozofije značajno mjesto daje problemima u tumačenju Platonove filozofije. Ali rad na tumačenju Platonove filozofije u velikoj je mjeri olakšan s obzirom na dostupnost svih Platonovih djela koje je povijest zapisala kao postojeća. Za razliku od Platonovog stvaralaštva, predsokratovski tekstovi su fragmentarni, što predstavlja ogromnu prepreku za detaljnu razradu predsokratovske filozofije. Nade povjesničara antičke filozofije za rad na novim tekstovima nakratko su bile vraćene 1994. godine s otkrićem Strazsburških papirusa sa stihovima Empedoklove poeme, kao i s Dervenijskim rukopisima (integralno objavljeni 2006. godine) u kojima 
se, preko orfičke teogonije, interpretiraju Anaksagora, Diogen iz Apolonije i Heraklit. Ipak, to nije bilo dovoljno da fundamentalno promijeni, dopuni ili olakša skiciranje slike predsokratovaca. Zbog ovog nedostatka, oni koji se bave predsokratovskom filozofijom oduvijek su imali specifičan zadatak ne samo da budu filološki arheolozi nego i da unaprijed fundiraju čvrstu metodološku osnovu nad kojom će pažljivo i nedvosmisleno graditi njihovu specifičnu predsokratovsku »priču«. Kao što kaže Mourelatos o predsokratovskoj filozofiji,

»... nijedna druga oblast ne nudi tako veliki izazov za filozofsku imaginaciju, kao i potrebu za složenim uvjetima za dokaznu i interpretativnu kontrolu«. ${ }^{1}$

Dugo vremena, proučavanje predsokratovske filozofije bio je dio instituta za klasičnu filologiju. Predsokratovski tekstovi predstavljali su više filološku nego filozofsku zagonetku. To nije vrijedilo u tolikoj mjeri za Platonovu i Aristotelovu filozofiju zato što, s izvjesnom lakoćom - iako, možda, ne toliko jednostavno - ona je mogla biti stavljena u suvremeni kontekst. Suvremenom povjesničaru filozofije mnogo bliža bila je, na primjer, diskusija o određenim pitanjima iz filozofije jezika kod Platona i Aristotela, nego diskusija o praosnovi kozmosa koja je dominantna kod predsokratovaca. Kada je predsokratovcima bilo vraćeno njihovo odgovarajuće filozofsko mjesto, trebalo ih je iznova pročitati. Prvo, tumačenja je trebalo distancirati od dominantne aristotelovske interpretacije prisutne kroz stoljeća, i drugo, bilo je potrebno revidirati metode tumačenja, pored filoloških. U ovom novom vraćanju na predsokratovsku filozofiju ona je trebala biti prihvaćena kao dostojan sugovornik suvremenom filozofu, na isti način na koji on komunicira s ostalom filozofskom tradicijom. Predsokratovce su presrele analitičke metode i demarkacijski znanstveni standardi. Kao kontrapunkt struji koja je isticala teorijski i racionalni angažman predsokratovaca, stajala je struja koja je isticala i njihovu praktičnu usmjerenost, gledajući filozofiju i kao način života (Nietzsche, Hadot). U tom smislu, u minulih stotinu godina, istraživanja na polju predsokratovske filozofije bila su izuzetno plodna. Uvedena su izuzetno suptilna mjerila u preciznosti interpretacije, re-evaluirani su istovremeno i primarni izvori i moderni komentari, ali postoji i stalno preosmišljavanje metodoloških standarda u svjetlu konkurentskih interpretacija.

Osnovne metodološke nedoumice s kojima se suočava povijest filozofije susreću se i u predsokratovskom kontekstu. Metodološki podložak predsokratovske filozofije mora odgovoriti na pitanja o tome tko su predsokratovci i što ustvari predstavlja predsokratovska filozofija; treba li govoriti o predsokratovskim filozofijama ili o predsokratovskoj filozofiji, naime, postoji li mogućnost za postavljanje osnove za sintezu predsokratovske filozofije na bazi nekog zajedničkog pitanja oko kojeg gravitiraju filozofska razmišljanja u ovom periodu ili neka specifična metoda s kojom se pristupa filozofskim pitanjima; mogu li se formulirati konkretne i specifične metode karakteristične za tumačenje predsokratovske filozofije; kakva je uloga povjesničara predsokratovske filozofije i njegova pristupa; kao i pitanje o potrebi filozofičnosti u interpretaciji predsokratovske filozofije, naime treba li tumačenje predsokratovske filozofije i samo biti filozofsko? Kroz ova pitanja bit će ukratko razmotreni povijesno-filozofski izazovi s kojima se suočava suvremena interpretacija predsokratovske filozofije.

\section{Tko su predsokratovci?}

Može li se govoriti o filozofiji prije Sokrata ili prije Platona? Što predstavlja predsokratovska filozofija? Tko su predsokratovci? Je li Dielsova lista predsokratovskih filozofa sveobuhvatna ili preširoka? 
Svako imenovanje jednog perioda iz prošlosti filozofije je povijesno-filozofska metodološka konvencija. To isto vrijedi i za predsokratovsku filozofiju. Interesiranje za proučavanje ovog perioda, kao problemski i povijesno samostalnog, nije suvremeno, nego dolazi još iz vremena neposredno poslije njega. Smatra se da je Hipija iz Elide posvetio jedan spis ranim filozofima, razrađujući ih na sistematski način. ${ }^{2}$ Sam termin »predsokratovci« u sekundarnoj literaturi učvršćen je Diels-Kranzovom zbirkom fragmenata Predsokratovci, na osnovu već uspostavljene pretpostavke da je riječ o kozmološkom periodu antičke filozofije koji završava Sokratovim antropološkim preokretom. Ipak, implikacije koje nosi sam termin uvode vrijednosno pristrane ocjene koje neophodno zahtijevaju kritičko preosmišljavanje samog termina. Oba sastavna dijela neologizma 'predsokratovci', i prefiks 'pred-' i Sokratova ličnost, su problematična.

Upotreba prefiksa 'pred-' otvara polemiku o tome ima li samo historiografsku ili problemsku konotaciju. Implicitno se postavlja pitanje o tome može li se otkriti napredak u antičkoj misli, pri čemu bi predsokratovci bili priprema, začetak i anticipacija velikana Antike. Neizbježna je interpretacija da to sa sobom nosi značenje njihovog niskog vrijednosnog situiranja u oblasti predfilozofske $\mathrm{i}$ arhaične ere, odnosno da je ta filozofija naivan prethodnik velikih Sokrata, Platona i Aristotela, ali i naivni prethodnik suvremene znanstvene misli. Prema Muhiću, u suvremenoj interpretaciji, predsokratovci su "prinuđeni biti epigoni $u$ anticipaciji cijelog oceana zabluda $\ll^{3} \mathrm{i} »$ pretvoreni su u duhovne liliputance« time što su na mapu filozofije stavljeni da bi se odazivali kao prethodnici jedne filozofije za koju nikad i nisu čuli.

S druge strane, Sokratova figura postavljena je kao referentna točka za pozicioniranje predsokratovaca, kao njihov povijesni i filozofski telos. Čime se odlikuje taj Sokratov period koji započinje novu eru u filozofiji i po čemu se razlikuje od njegovih prethodnika? Windelbandova klasifikacija antičke filozofije na kozmološku, antropološku i sistematsku filozofiju postala je klasična podjela u sekundarnoj literaturi. Pojavom Sokrata, na filozofskoj sceni pravi se razlika između ispitivanja »prirodnih« i »ljudskih« stvari, između ispitivanja »teorijskog « i »praktičnog «. I sam Sokrat, u obrani pred Atenskim sudom, distancirao se je od optužbi za ispitivanje »onog što je pod zemljom i onog što je na nebu«. ${ }^{4}$ Prema Ciceronu, Sokrat je onaj koji je »prvi skinuo filozofiju s neba«..$^{5}$ Ali ako je pitanje čovjeka i morala ključna osovina oko koje gravitira Sokratova filozofija, onda zašto se u obzir ne uzimaju sofisti? I Dielsova zbirka sadrži fragmente mnogih filozofa koji su bili Sokratovi suvremenici, a neki su ga i nadživjeli.

Zbog svega toga, postavljaju se alternativni nazivi koji bi označavali ovaj period. Neki povjesničari umjesto na »predsokratovske filozofe« pozivaju se na »predsofističke filozofe « (Cleve) ili na »predplatonovce« (Nietzsche), dok drugi, s ciljem izbjegavanja prefiksa 'pred-' kao teorijski neodgovarajućeg

1

Alexander P. D. Mourelatos (ur.), The PreSocratics: A Collection of Critical Essays, Princeton University Press, Princeton 1993., str. 3.

2

DK 86B6.

Ferid Muhić, Potomci na bogovite, Taberna-

kul, Skopje 2005., str. 29.
4

Platon, Odbrana Sokratova, u: Platon, Dela (Ijon, Gozba, Fedar, Odbrana Sokratova, Kriton, Fedon), Dereta, Beograd 2002., 19c.

5

Ciceron, Rasprave u Tuskulu, Srpska književna zadruga, Beograd 1974., str. 154, 5. 4. 10. 
i vrijednosno nedostojnog, pribjegavaju k njihovom imenovanju kao »prvih filozofa«, koje se sreće još kod Aristotela, ili pak kao »ranih grčkih filozofa« (Burnet, Long). Muhić, shvaćajući filozofe kao nasljednike božanstvenog roda stanovnika Atlantide, predsokratovce naziva »potomci bogova«. Ipak, termin 'predsokratovci' još uvijek ne gubi svoje mjesto u akademskoj konvencionalnoj terminologiji, upotrebljavajući se u velikoj mjeri po inerciji ili zbog njegove funkcije koja se pokazala kao praktična.

Može li se govoriti o jednoj generalnoj filozofiji, makar i nazvana »predsokratovskom filozofijom «, koja je karakteristična za navedeni period? Tendencija da npr. Tales, Pitagora, Heraklit, Parmenid ili Empedoklo budu kategorizirani u jednu grupu nije suvremena kategorizacija. Objedinjavajući njihova učenja na osnovu koncepta physisa, i Aristotela i Teofrasta svrstavaju u grupu koja nosi naziv »fizičari« ili »fiziolozi«. Potkategorije se unose još kod Diogena Laertija koji ih dijeli na jonsku i italsku grupu, s kasnijom suvremenom intervencijom prema kojoj se prvi smatraju za prirodnjake, a drugi za mistike. U nekoliko primjera (Zeller, Überweg) pitagorejci i elejci tretiraju se zasebno, a jonjani i ostali predsokratovci grupirani su u zasebne cjeline. Prema Windelbandu, glavni metafizički konflikt u predsokratovskoj filozofiji događa se između filozofije Heraklita i elejaca, dok Empedoklo, Anaksagora, atomisti i pitagorejci predstavljaju pokušaj rješavanja tog konflikta. Ipak, prema mnogim parametrima, predsokratovci dijele isti pogled na svijet. Copleston taj pogled na svijet naziva »metafizička intuicija«. ${ }^{6}$ Čitajući fragmente predsokratovaca, zapaža se da se ponavlja implicitna artikulacija filozofskih pitanja: tu je pitanje o podležećem, prvom, primordijalnom; o granicama kozmosa; o jednom i o mnoštvu; o čulnom i o razumskom saznanju. Sva ova pitanja postavljaju se kroz dvije teorijske specifičnosti: prvo, one su generalizirajuće i teže k sveobuhvatnosti, odnosno sve što postoji gleda se pod vidom univerzalnog, kozmičkog; i drugo, one imaju etiološki karakter, odnosno sve što postoji gleda se pod vidom njegovog prapočetka, njegove podležeće osnove. Zato se zajedno ispituju kozmogonija i kozmologija, zoogonija i zoologija. Etička zainteresiranost nije sekundarna problematika, kao što se uobičajeno smatra, nego je implicitno prihvaćena tradicionalna etika mudraca, izražena kroz proročanstva i etičke preporuke sedam mudraca. S metodološkog aspekta, ovi parametri dovoljni su za označavanje jedne povijesno-filozofske cjeline, o čemu svjedoči najveći broj periodizacija u interpretativnoj literaturi. Imenovanje perioda, kao i kriteriji potpodjele, ostaju teorijske preference povjesničara filozofije.

\section{Filozofičnost interpretacije predsokratovaca}

Gledište da povijest filozofije predstavlja čistu historiografiju u velikoj mjeri je napušteno. Još od Bruckerove Historia critica philosophiae problematizira se stav da je povijest filozofije navođenje značajnih činjenica o povijesti filozofije i da je ona čisto filozofska djelatnost ako povjesničar filozofije može sagledati povijest u cjelini. Povjesničar filozofije primarno je filozof, a ne povjesničar ili filolog, a povijesno-filozofski osvrt treba, prije svega, biti filozofičan.

Međutim, osnova svake povijesno-filozofske analize je neposredno tekstualno svjedočanstvo i zbog toga je filološka analiza značajan dio svake interpretacije. Ona ne samo što je značajna nego je i neophodna za tumačenje jednog filozofskog perioda u kome je tekstualno svjedočanstvo oskudno. Ali dominantnost filološke analize, upravo zbog toga što je analitički usmjerena, 
izostavlja sintezu filozofskih učenja u jednom povijesnom kontekstu. U mnogobrojnim povijesno-filozofskim osvrtima na predsokratovsku filozofiju, naročito do sedamdesetih godina dvadesetog stoljeća, metode filološke analize bile su najviše zastupljene u tumačenju, čime je interpretacija imala više filološki nego filozofski prizvuk. Filozofski tekstovi bili su tretirani na isti način na koji se tretirao epski stih ili bilo koji drugi žanr u antici, samo zbog toga što su napisani na istom jeziku i u istom vremenskom periodu. Interpretacija je detaljna, suptilna, mikroskopski precizna, analitična, deskriptivna, apodiktična. Cleve za klasične filologe kaže:

»... oni imaju sve odgovore, ali ne znaju pitanja«.?

Kao reakcija u potrazi za sveobuhvatnom interpretacijom, otvorilo se pitanje o filozofičnosti interpretacije. Pitanje o ovoj karakteristici interpretacije postavilo je filozofsku sintezu nasuprot dominantnoj filološkoj analizi. ${ }^{8} \mathrm{Kao}$ klasična rasprava o tipično problematskom i filološkom pristupu u interpretaciji tretira se ona koju vode Kirk i Popper, upravo na predsokratovskom terenu. ${ }^{9}$

S jedne strane filološka analiza, sa svojim mikroskopskim pristupom, rekonstruira tekst, teži očuvanju izvornog senzibiliteta u izražavanju ideja i drži se veoma blizu teksta. S druge strane filozofska sinteza, koja rekonstruira ideje, teži njihovoj pretjerano slobodnoj interpretaciji. U slučajevima kada su dovedene do ekstrema, filološka analiza rezultira unutrašnjom i kontekstualnom nekoherentnošću, nemajući u vidu cjelinu; dok filozofska sinteza, i pored toga što osigurava cjelinu i kontekst, može potpuno izmijeniti tumačeni materijal i »pogađati« s ciljem da »zakrpa« nedostupna mjesta. Nedostatke ekstremno izvedene filozofske sinteze predsokratovske filozofije primjećujemo još u Aristotelovoj Metafizici, uklopljene u njegov filozofski diskurs, a mnogo kasnije i u Hegelovom osvrtu; isto kao što se filološka analiza na djelu pokazuje kod Kirka i Ravena.

Međutim, ova dihotomija u suvremenim analitičko-povijesno-filozofskim osvrtima bila je zamijenjena s jednom novom interpretativnom praksom tzv. filozofske analize. Partikularističke tendencije dvadesetog stoljeća u okvirima same filozofije reflektirale su se i na prakse tumačenja predsokratovske filozofije preko korištenja metodološke analitičke Russellove preporuke »podijeli pa vladaj«. Dijelovi, rečenice, pa čak i manje fraze i termini iz filozofskih

Frederick Copleston, A History of Philosophy, Vol. 1 (Greece and Rome), Doubleday, New York 1993., str. 76

Felix M. Cleve, The Giants of Pre-Sophistic Greek Philosophy, Vol. 1, Martinus Nijhoff, Haag 1973., str. 6.

Distinkciju filološke analize i filozofske sinteze djelomično preuzimamo upravo od Clevea koji pretendira napraviti filozofsku rekonstrukciju predsofističke filozofije, smatrajući da je filološka rekonstrukcija gotovo nemoguća. Senekinu dijagnozu »philologia facta est, quae philosophia fuit« želi zamijeniti $\mathrm{s}$ formulacijom »Philosophia fiat, quae philologia fuit!«. Vidi u Felix M. Cleve, »Understanding the Pre-Socratics: Philological or
Philosophical Reconstruction?«, International Philosophical Quarterly, god. 3 (3/1963), str. 445-464, doi: http://dx.doi.org/10.5840/ ipq19633317; i u F. M. Cleve, The Giants of Pre-Sophistic Greek Philosophy.

9

Vidi Karl R. Popper, »Back to the Presocratics «, Proceedings of the Arisotelian Society, god. 59 (1958), str. 1-24; Geoffrey S. Kirk, »Popper on Science and the Presocratics«, Mind, vol. 69 (1960), str. 318-339, doi: http:// dx.doi.org/10.1093/mind/lxix.275.318; Karl R. Popper, »Appendix: Historical Conjectures and Heraclitus on Change «, Conjectures and Refutations: The Growth of Scientific Knowledge, Routledge, London 2002., str. 206-224, doi: http://dx.doi.org/10.4324/978 0203538074 
predsokratovskih tekstova uzimaju se kao posebne cjeline i analiziraju se kao posebne logičke cjeline same po sebi. Analizira se postoji li validan argument ili zaključak i jesu li zaključci pravilni ili nepravilni prema logičkim zakonima. Preferiraju se partikularni stavovi, umjesto filozofskih sistema, kao i argumenti koji se daju za te stavove. U ovoj analitičkoj tendenciji, simbolička logika najznačajniji je organon za vrednovanje argumenata. Dokle doseže logička smišljenost dotle se proteže fillozofičnost ovog vida interpretacije.

Zadatak povjesničara filozofije predsokratovaca ima trojnu ulogu: prvo, osigurati odgovarajuću faktografsku informaciju za filozofiju predsokratovaca onoliko koliko dozvoljavaju svjedočanstva; drugo, tumačiti, naime dati široka poopćenja kako filozofskih argumenata, tako i opće filozofske predsokratovske klime, ali i ponuditi rješenja prijevoda ideja predsokratovaca na jeziku i u pojmovnom okviru svog vlastitog vremena, s ciljem određivanja njihovog značenja i važnosti, i treće, vrednovati nekog predsokratovskog filozofa, neku ideju, neki argumenti, ili cijelo predsokratovsko razdoblje. Filološku analizu osigurava prva, kao i dio druge etape interpretacije, dok filozofsku sintezu osigurava dio druge etape, kao i treća etapa koja predstavlja stvaralačku funkciju interpretacije. Kao što kaže Šijaković, filološka analiza, time što »ustanovljuje, ima primarno reduktivnu funkciju, dok je filozofska interpretacija, zbog toga što stalno na plodan način »uspostavlja«, ona koja osigurava produktivnost. ${ }^{10}$ Sto se, pak, tiče filozofske analize, ona je po svom pristupu filozofska, ali svoje istraživanje ne proširuje na izvjesne aspekte, kao što su povijesni, kulturni i jezički konteksti, koji su izuzetno važni za povijesno-filozofsku djelatnost. To proizlazi iz ahistoričnosti koja se implicitno prihvaća u filozofskoj analizi.

Davanje razloga za filozofske zaključke, otkrivanje skrivenih premisa u filozofskim argumentima i kontekstima i logička evaluacija filozofskih stavova, sve je to samo po sebi filozofska aktivnost. Povijest filozofije, iako potpada pod kategoriju »sekundarne« literature, ipak nije »drugorazredna« literatura. Ona je sama po sebi filozofsko djelo. Povjesničar predsokratovske filozofije još odavno nije primarno ni filolog ni povjesničar, već filozof. U povijesnofilozofskom dijalogu postoji argumentativna razmjena između filozofa i filozofa, a ne između povjesničara/filologa i filozofa. Njegova uloga, iskazana diltajevskim terminima, je »razumijevajuća« a ne »objašnjavajuća«. U tumačenju, važan je faktor uvjerljivosti, a ne demonstracija povijesne i filološke reprodukcije, komentatorska funkcija i interpretacija.

\section{Suvremene tendencije - ogledala prošlosti}

S ushićenošću od upitanosti o granicama kozmosa i o njegovoj zakonomjernosti, s počecima uspostavljanja znanstvenog duha, s uzdizanjem moći čovjekovog razuma, lako se povezao današnji filozof. U suvremenim odjecima predsokratovske filozofije ukrstile su se sve nedoumice današnje filozofije.

Iz aspekta reaktualizacije ili tekstova, ili uloge jednog filozofa, najviše je zastupljena, kao prvo, Empedoklova filozofija u svjetlu Strazburških papirusa i mogućnosti za pomirenje njegovih dviju filozofskih tendencija izraženih u dvjema poemama $O$ prirodi i Pročišćavanje; zatim pitagorejci s obzirom na njihovu filozofsku kontroverznost i mističku usmjerenost, naročito poslije Burkertove studije iz 1964. godine u kojoj se problematizira uloga Pitagore kao autoriteta škole; treće, prepoznavanje Ksenofona kao značajne predsokratovske figure, naročito poslije Lesherove knjige Ksenofon iz Kolofona iz 1992. godine. Iz teorijskog aspekta, Parmenid i Heraklit još uvijek ostaju 
filozofski najizazovnije ličnosti. Možda Demokrit i Anaksagora ne privlače toliko pažnju povjesničara filozofije, ali zato se imena koja nisu toliko karakteristična za povijesno promišljanje, poput Diogena iz Apolonije, spominju sve češće.

Konceptualni, kao i metodološki imperativi kontinentalne i analitičke filozofije došli su do izraza u tumačenju predsokratovaca. Ipak, i pored njihovih oštrih neslaganja, oni nisu žrtvovali predsokratovsku filozofiju.

$\mathrm{Za}$ analitičku filozofiju, predsokratovci su značajan dio "prosvjetiteljskog projekta ( the Enlightenment project) kao začetnici racionalne argumentacije. Osnovne metodološke pretpostavke su one koje su karakteristične za gore objašnjeni pristup filozofske analize. Najznačajnija komponenta analitičke interpretacije je analiza konceptualne strukture misli oslobođene od povijesnih, biografskih i socio-kulturnih konteksta. Postoji racionalna rekonstrukcija filozofskih sistema izvan konteksta u kojem su stvoreni.

Parmenid je ključna filozofska ličnost u predsokratovskoj filozofiji zbog njegove sklonosti lingvističkim i logičkim analizama. Zato se veoma često u analitičkim povijesno-filozofskim osvrtima može sresti podjela na pred- i poslijeparmenidovske filozofe. Akcentiranje uloge Parmenida u predsokratovskoj filozofiji još više ilustrira ponovno objavljivanje Mourelatosove knjige The Route of Parmenides u 2008. godini, kao klasična interpretacija u studijama Parmenida.

Pitanje o tome kako nam predsokratovci mogu odgovoriti na naše suvremene probleme potaklo je analitičko interesiranje za pronalaženje početaka znanstvenog mišljenja kod predsokratovaca. Tako nove filozofske discipline, kao što su filozofija uma, filozofija fizike i filozofija biologije, koje primarno duguju svoj napredak napretku odgovarajućih znanosti, svoje početke traže upravo kod predsokratovaca. Na primjer, Algra miletske filozofe naziva »protoznanstvenicima «. ${ }^{11}$ Prema ovakvom pristupu, mnogi od već oskudnih fragmenata otpadaju kao relevantne teze za dijalog i ono što ostaje, slijedeći ove kriterije, čini se da više pripada povijesti znanosti negoli povijesti filozofije. Patricia Curd, u svojoj studiji u kojoj analizira najnovije članke povezane s predsokratovskom filozofijom (do 2011. godine), zaključuje da se ova istraživanja najviše fokusiraju na prirodne fenomene koje istražuju predsokratovci, kao što su: nebeska tijela, kometi i meteori, meteorološke pojave, rijeke i mora, zemljotresi. ${ }^{12}$

Za kontinentalnu filozofiju, pak, glavna figura kod predsokratovaca je Heraklit. Zbog uspostavljanja principa fluktuiranja i nepostojanosti u njegovoj filozofiji, njega mnogi, počevši od Hegela, preko Nietzschea i Heideggera, pa sve do postmodernizma, smatraju filozofski najinspirativnijim predsokratovskim misliteljem. Generalno, kontinentalna interpretacija afirmira validnost neposrednog iskustva u određenom kontekstu (jezik, kultura, povijest, rod), ali i kontekstualne elemente egzistencijske dimenzije čovjekovog života. Hadot kaže:

10

Bogoljub Šijaković, Mythos, Physis, Psyche, Jasen, Beograd, Nikšić 2002., str. 18.

11

Keimpe Algra, »The Beginnings of Cosmology«, u: Anthony A. Long (ur.), The Cambridge Companion to Early Greek Philosophy, Cambridge University Press, Cam- bridge 1999., str. 45-65, doi: http://dx.doi. org/10.1017/CCOL0521441226.003.

12

Patricia Curd, »New Work on the Presocratics «, Journal of the History of Philosophy, god. 49 (1/2011), str. 6 . 
»... s ciljem da se razumiju djela filozofa antike, moraju se uzeti u vidu sva konkretna stanja u kojima su pisali, sve prepreke koje su ih ometale, forma škole, priroda philosophia, književni žanrovi, retorička pravila, dogmatski imperativi i tradicionalni načini razmišljanja. «13

Iako ne u povijesnoj maniri, ipak veliki utjecaj u kontinentalnom shvaćanju predsokratovaca imaju Nietzsche i Heidegger. Kao uspješan spoj života i mišljenja, predsokratovci, prema Nietzscheu, najbolje ilustriraju istiniti grčki duh, naime izbalansirani spoj dionizijskog i apolonijskog. Sa Sokratovom »odvratnom pretenzijom na sreću ${ }^{14}$ pojavljuje se »teoretski čovjek«, a ne s predsokratovcima. Smatrajući ih za najveće pronalazače, on smatra da sva kasnija pokoljenja nemaju što naknadno dodati njihovim otkrićima. Heidegger, pak, kod predsokratovaca sagledava imanentni pristup neposrednog iskustva bitka. Prema njemu, oni nisu rani znanstvenici ili racionalni filozofi, već mislioci koji sagledavaju bitak kao neskrivenost (aletheia). Ova kritika upotrebe scijentističke metodološke aparature u tumačenju, kao i protivljenje tumačkoj redukciji predsokratovaca na začetnike suvremene znanosti, postaje jedna od karakteristika kontinentalnog pristupa $\mathrm{k}$ interpretaciji predsokratovaca. Izuzetno žestoka kritika ovog specifikuma analitičkog pristupa je ona kod Muhića, izražena u Barnesovom djelu Predsokratovski filozofi.

Možda je prevelika suvremena impresioniranost predsokratovskom filozofijom djelomično razlog za pojavljivanje interpretativnih matrica koje ne zadovoljavaju ni minimum kriterija za metodološku adekvatnost u tumačenju. Stereotipe koje se najčešće sreće u interpretiranju antičke filozofije Georgieva ${ }^{15}$ dijeli na: scijentistička orijentacija i projekcija mišljenja. Ona ih naziva »stereotipi« zbog njihove već uspostavljene hegemonije jedinstvenih interpretativnih »uzoraka«, »okorjelih, 'stvrdnutih', ukrućenih i stegnutih istraživačkih modela «, ${ }^{16}$ preko kojih se »izvode apriorističke konstrukcije s jednodimenzionalnom i iskrivljenom slikom antičke filozofije «. ${ }^{17}$ Lebedev isto tako sintetizira »interpretativne mitove« o predsokratovskoj filozofiji u četiri grupe: pozitivistički mit iz 19. vijeka (Burnet, Gomperz, Tanery), ničeanski mit koji idealizira grčke filozofe iz »tragičke« ere, hajdegerijanski mit koji se zasniva na nejasnim etimologijama te epistemološki i antiteološki mit Poppera (revitalizacija pozitivističkog mita iz 19 . vijeka). ${ }^{18}$ Prateći generalne tendencije suvremenih interpretativnih zahvata prema predsokratovskoj filozofiji, kao dominantne karakteristike možemo navesti partikularizam, anakronizam i teleologizam. Zbog proliferacije metodološki neprikladnih pristupa, u zadnja dva desetljeća postoji tendencija reevaluacije i autorefleksije metodoloških postupaka u tumačenju predsokratovske filozofije, koja se pokazuje u sve češćoj potrebi za održavanjem interdisciplinarnih dijaloga na tu temu. Jedan takav dijalog je tradicionalni Symposium Praesocraticum, ustanovljen 2000. godine, koncipiran prema uzoru na druge događaje sličnog formata (Symposium Aristotelicum, Symposium Platonicum, Symposium Hellenisticum), kao i osnivanje udruženja (npr. International Association for Presocratic Studies) čiji članovi dolaze iz različitih interpretativnih tradicija.

\section{Zaključne primjedbe}

Povijest filozofije treba stalno iznova iščitavati filozofiju iz prošlosti. To nije jednom zauvijek završeni proces. Njena uloga je da iznova problematizira stare filozofske koncepte u novoj terminologiji, novim jezicima, novim perspektivama, novim pogledima na svijet. Zbog toga se susrećemo s tezom o »zastarjelim« i »suvremenim« osvrtima na povijest filozofije. Ona nije samo umjetni reanimator prošlosti filozofije, nego njen živi sugovornik. Ona omo- 
gućava da sadašnjost uvijek ima pristup prošlosti filozofije, suočavajući se s izazovom održavanja ove veze sukladno zahtjevima prošlosti i sadašnjosti. Najveći od njih je da se pomiri s kontekstualnošću prošlosti i transtemporalnošću ideja koje zahtijeva sadašnjost. Specifična senzibilnost povjesničara filozofije zahtijeva od njega da se, shvaćajući potrebu filozofske tendencije čiji je i sam plod, transponira u kontekst s drukčijim filozofskim kodom. Zato, kategorički metodološki imperativ je odgovoriti na pitanje o pojmu filozofije i u sadašnjem i u specifičnom povijesnom kontekstu koji se tumači. Mogućnost da dio filozofskog konteksta prošlosti ostane nepristupačan je rizik koji prihvaća svaki povjesničar filozofije. Smisao za ponovno vraćanje k prošlosti filozofije nije da bi našli gotove odgovore na naše današnje probleme, nego da nas oni, primjereno shvaćeni u njihovom povijesnom kontekstu, potiču da preosmislimo naše današnje nedoumice i shvaćanja.

Nemoguće je da se povjesničar filozofije u cjelini izuzme od svojih ispitivanja. On je zbir određenih konkretnih koordinata: konkretnog jezika, paradigme pogleda na svijet. Neizbježna je činjenica da je suvremeno čitanje povijesti filozofije ogledalo te povijesti u sadašnjosti. Ono reflektira ideje prošlosti suglasno s njegovim specifičnim reflektirajućim uglom. Svakako, sadašnjost je za povjesničara filozofije sasvim značajan i određujući faktor, ali bez ispunjavanja zahtjeva prošlosti ona ostaje sasvim »gluha«. Voegelin kaže da

»... nije moguća adekvatna interpretacija jednog velikog djela, sve dok interpretator ne preuzme ulogu učenika koji sve mora naučiti od svog učitelja«. ${ }^{19}$

Pripremljena očekivanja i zaboravljanje cilja istraživanja su velike klopke u koje može upasti povjesničar filozofije.

Uvjete koje jedna interpretacija treba zadovoljiti u tumačenju antičke filozofije, Georgieva ${ }^{20}$ sumira u sljedeća dva: faktografska potkrijepljenost s filološkim saznanjima i imanentna kritika. Uz spomenute, dodajemo i princip logičke dosljednosti interpretacije. Kao prvo, uvjet za direktno pozivanje na interpretaciju primarnih izvora jedne filozofije iz prošlosti ne treba posebno predočavati, on se mora podrazumijevati. Nisu česti primjeri kao Fodor ${ }^{21}$ koji smatra da se može pisati o jednom filozofu iz prošlosti i pored toga što se o

13

Pierre Hadot, Philosophy as a Way of Life. Spiritual Exercises from Socrates to Foucault, Blackwell, Malden 1995., str. 61

14

Fridrih Niče [Friedrich Nietzche], Knjiga $o$ filozofu, Grafos, Beograd 1984., str. 99.

15

Vera Georgieva, »Stereotipi vo tolkuvanjeto na antičkata filozofija«, u: Valerij Sofronievski (ur.), Antikata i evropskata nauka i kultura, Filozofski fakultet, Skopje 2009., str. 37.

16

Ibid.

17

Ibid. str. 38 .

18

Andrei V. Lebedev, »Getting Rid of 'Presocratics'", u: Philosophy in the Dialogue of Cultures. Materials of the World Philosophy
Day (Moscow - St. Petersburg, November 16-19, 2009), str. 177-183. Dostupno na: http://www.fks.uoc.gr/greek/CVs/Lebedev/ Lebedev Getting\%20rid\%20of\%20 Presocratics \%202009.pdf (pristupljeno 7. studenoga 2015.).

19

Charles R. Embry (ur.), Robert B. Heilman and Eric Voegelin: A Friendship in Letters, 1944-1984, University of Missouri Press, Columbia, London 2004., str. 150.

20

V. Georgieva, »stereotipi vo tolkuvanjeto na antičkata filozofija«, str. 46.

21

Jerry A. Fodor, i pored njegovog svjesnog nepoznavanja povijesti filozofije, smatrao je da iako ne zna ništa o Humeu, može napisati knjigu o njemu, što je ideja koju kasnije ostvaruje u Hume Variations. 
njemu ništa ne zna, ali ipak, česta je tendencija da se ocjene o jednom filozofu izvlače iz sekundarne literature. Poznavanje originalnog jezika, naročito za predsokratovsku filozofiju, je ključno zato što sama priroda starogrčkog jezika »raspliće« specifičan pogled na svijet predsokratovskog autora. Kao drugo, kod povijesno-filozofskog osvrta jedan povjesničar svoju djelatnost kao tumač treba ograničiti na referentni sistem autora kojeg tumači, a ne na svoj ili na neki drugi sistem koji preferira. Neodgovarajuće metodološko pravilo značilo bi još od početka prihvatiti princip u tumačenju koji će unaprijed postaviti »sudbinu« interpretirane povijesti u neku teoriju koja je preferirana. Postavljanje teleološke povijesti filozofije je preslika općeljudskog nagona da vidi ono što ne zna prema onome što zna. A to nije ekskluzivno samo za neku konkretnu tradiciju. U duhu Heraklitove preporuke i za povjesničara filozofije važilo bi sljedeće:

»Ako čovjek ne očekuje neočekivano, neće ni ga otkriti $[\ldots] . \ll$

Kao treće, postavljamo uvjet da interpretacija ne bude kontradiktorna sama sebi i da poštuje svoju imanentnu koherentnost. Prvobitno uspostavljeni metodološki principi moraju biti cjelovito logički izvedeni u svakom segmentu interpretacije.

Ipak, ovo su minimalni uvjeti potrebni za odgovarajuću interpretaciju, a ne maksimalni i posljednji. Filozofski nagon ne dozvoljava, naročito kada je riječ o autorefleksivnim standardima istraživanja, da njih ostavi zauvijek definirane. Njih treba stalno preosmišljavati. Kao što je u prirodi filozofije da ona stalno bude otvorena i nezavršena, u tome je mora slijediti povijest filozofije tako da bi i ona sama ostala filozofična.

\title{
Jasmina Naumoska \\ Contemporary Methodological Challenges in Interpreting Presocratic Philosophy
}

\begin{abstract}
The history of philosophy, seen as an activity of perpetual rereading of philosophy's past in the light of new contexts, always has to be faced with the interpretative methodological challenges of its own time. The contemporary interpretation of the Presocratics has to: give anew an answer to the question of what represents the Presocratic philosophy; determine the interpretive approach in accordance with the methods that are used during that process; evaluate how much today's world view can digress from historic-philosophical reality; but also establish minimum standards for methodologically appropriate interpretation.

Within this theoretical framework, through detecting some contemporary interpretative tendencies of the Presocratic philosophy, this text problematizes the identity of the Presocratics, analyzes the approaches of "philosophical synthesis", "philological analysis" and "philosophical analysis", brings out the endeavors for overcoming certain interpretive stereotypes, but also lays down the founding conditions for a methodologically opportune interpretation. In addition, this paper points out, analogously to the view-point that philosophy is an open and endless process, the opinion that history of philosophy, as immanently philosophical discipline, cannot lay down permanent methodological standards.
\end{abstract}

Key words

Presocratics, interpretation, methodology, contemporary philosophy 